\title{
INTEGRATED FLOOD DISASTER MANAGEMENT AND SPATIAL INFORMATION: CASE STUDIES OF NETHERLANDS AND INDIA
}

\author{
Sisi Zlatanova ${ }^{\mathrm{a}}$, Tarun Ghawana ${ }^{\mathrm{b}}$, Amarjeet Kaur $^{\mathrm{b}}$, Jeroen M.M. Neuvel ${ }^{\mathrm{c}}$
}

\begin{abstract}
${ }^{a}$ Faculty of Architecture, Jullianalaan, TU Delft, 134, 2628BL Delft, The Netherlands- s.zlatanova@tudelft.nl
${ }^{\mathrm{b}}$ Centre for Disaster Management Studies, Guru Gobind Singh Indraprastha University, Sector-16C, Dwarka, New Delhi,

P.O. Box-110078, India - tarungh@gmail.com; amarjeet_ip@yahoo.com

${ }^{\mathrm{c}}$ Saxion University of Applied Sciences, Risk management, Handelskade 75, 7417 DH Deventer, The Netherlands j.m.m.neuvel@saxion.nl
\end{abstract}

KEY WORDS: Floods, Spatial Information Infrastructure, GIS, Risk Management, Emergency Management

\begin{abstract}
:
Spatial Information is an integral part of flood management practices which include risk management \& emergency response processes. Although risk \& emergency management activities have their own characteristics, for example, related to the time scales, time pressure, activities \& actors involved, it is still possible to identify at least one common challenge that constrains the ability of risk \& emergency management to plan for \& manage emergencies effectively and efficiently i.e. the need for better information. Considering this aspect, this paper explores flood management in Netherlands\& India with an emphasis on spatial information requirements of each system. The paper examines the activities, actors \& information needs related to flood management. Changing perspectives on flood management in Netherlands are studied where additional attention is being paid to the organization and preparation of flood emergency management. Role of different key actors involved in risk management is explored. Indian Flood management guidelines, by National Disaster Management Authority, are analyzed in context of their history, institutional framework, achievements and gaps. Flood Forecasting System of Central Water Commission of India is also analyzed in context of spatial dimensions. Further, information overlap between risk \& emergency management from the perspectives of spatial planners \& emergency responders and role of GIS based modelling / simulation is analyzed. Finally, the need for an integrated spatial information structure is explained \& discussed in detail. This examination of flood management practices in the Netherlands and India with an emphasis on the required spatial information in these practices has revealed an increased recognition of the strong interdependence between risk management and emergency response processes. Consequently, the importance of an integrated spatial information infrastructure that facilitates the process of both risk and emergency management is addressed.
\end{abstract}

\section{INTRODUCTION}

Disaster management activities have their own characteristics e.g., related to the time scales, time pressure, activities and actors involved - and the stakeholders involved in different activities have their own system requirements, it is still possible to identify at least one common challenge that constrains the ability of risk and emergency management to plan for and manage emergencies effectively and efficiently: the need for better information (Cutter et al. 2003; Parker et al. 2007; Zlatanova et al. 2007; Fiedrich, and Zlatanova, 2013; Kaviani et al., 2014). Geospatial Information Systems are increasingly seen as indispensable in supporting disaster management activities (Brazier and Greenwood 1998; Contini et al. 2000; Greene 2002; Craciunescu et al. 2006; Köhler and Wächter 2006; Parker et al. 2007; Pattusamy et al. 2014).

The paper explores flood management in Netherlands and India with an emphasis on the role of spatial information. It tries to understand the components of flood management system in the both countries. The paper examines the activities, stakeholders $\&$ information needs related to flood management. The case study in the Netherlands is based on previous research, in which the spatial information requirements were explored through a literature study, interviews and workshops (Neuvel 2009, Chapter 7).

\section{RISK \& EMERGENCY MANAGEMENT AND GIS}

Normally, risk and emergency management activities are divided into pre-event activities consisting of mitigation and preparation activities and post-event activities including response and recovery activities. However, it has been suggested to merge preparation and response activities since many GIS systems developed in the preparation phase are utilised in the response phase (Cova 2005; Zlatanova, and Fabbri, 2009).

In case of preparation phase, modelling and simulation exercises are very important which can help towards prevention, adaptation and mitigation processes. In GIS arena, water resources management applications have most efficiently harnessed its analytical capacities to create bio-physical models and simulation runs, for eg. Hydrological Models and Hydraulic Models (MIKE11 and HEC-RAS). These systems in an integrated form can predict flood behaviour taking inputs of various terrain, landcover / landuse and hydro-meteorological datasets to. In a manner, they work as Spatial Decision Support Systems (SDSS).

In response phase, this information along with infrastructural data in spatial and non-spatial form can be used to enhance the efficiency of response. Optimization of routes by response teams based on the real time data of the affected areas could easily save time and resources while responding. Satellite imageries of the disaster event can provide the information about the extent of flooded areas. Using Depth or volume 
information from the previously run simulation exercises, responsible agencies can find out the possible depth or volume of water in the flood area. They can also find out the proneness of further areas to be affected by the flood water reaching in those areas.

\section{FLOOD MANAGEMENT IN THE NETHERLANDS - CHANGING PERSPECTIVES}

Dutch flood management strategies are traditionally aimed at reducing the probability of flooding through more than 3,600 $\mathrm{km}$ of primary dikes that directly protect the hinterland from flooding by the sea or major rivers (Ministerie van VerkeerenWaterstaat and InspectieVerkeerenWaterstaat 2006). Nevertheless, this flood risk management strategy has been changing since the 1990s. After the flooding of unprotected areas in the river foreland of the Meuse in 1993 and 1995 and a near flooding event of the dike ring areas along the Meuse and Rhine in 1995, flood risk policies were changed and river dikes were raised at various places. This action was supported by a plan which allowed for the largest rivers to be given greater freedom to spill out across some parts of their original floodplains. The plan, which became known as the 'Room for the River' Policy, entailed the removal of obstacles from the floodplains, dike relocation, and the creation of retention areas, bypasses and secondary channels to circumvent urban bottlenecks.

Dutch government, in particular, Ministry of Transport, Public Works and Water Management are considering the need for additional mitigation measures to reduce the consequences of flooding (Ministerie van VerkeerenWaterstaat 2007). Land use planning is also being seen an important instrument.

In the last decade, various projects were also funded for developing early warning systems (estimating also measurements from water level gauges) and information systems to support the communication between actors involved in emergency response. These improvement efforts also included improving cooperation with neighbouring countries (STOWA 2008; Minister van Infrastructure en Milieu Interprovincial Overleg IPO \& Unie van Waterschappen 2012).

\subsection{Flood Risk Management in the Netherlands}

Risk management activities and processes can be grouped into four clusters: 1) identification, 2) risk assessment or evaluation, 3 ) choice and implementation of risk reduction measures and instruments, 4) monitoring and maintenance of the acceptable risks (Bottelberghs 2000; Schanze 2006). Table 1 gives an overview of key actors in Dutch flood risk management practices.

Table 1: Key Stakeholders Involved in Risk Management

\begin{tabular}{|lll|}
\hline Activities Key Staekholders \\
\hline $\begin{array}{l}\text { Identification of flood } \\
\text { risks }\end{array}$ & $\begin{array}{l}\text { Ministry of Infrastructure and the } \\
\text { Environment, provinces, water boards }\end{array}$ \\
\hline $\begin{array}{l}\text { Evaluation and } \\
\text { assessment of flood } \\
\text { risks }\end{array}$ & $\begin{array}{l}\text { Ministry of Infrastructure and the } \\
\text { Environment, provinces, municipalities, } \\
\text { water boards, emergency services, non- } \\
\text { governmental stakeholders }\end{array}$ \\
\hline $\begin{array}{l}\text { Choice and } \\
\text { implementation of risk } \\
\text { reduction measures } \\
\text { and instruments }\end{array}$ & $\begin{array}{l}\text { Ministry of Infrastructure and the } \\
\text { Environment, provinces, municipalities, } \\
\text { governmental stakeholders }\end{array}$ \\
\hline $\begin{array}{l}\text { Monitoring and } \\
\text { maintenance of the } \\
\text { acceptable risks }\end{array}$ & $\begin{array}{l}\text { Ministry of Infrastructure and the } \\
\text { Environment, water boards. }\end{array}$ \\
\hline
\end{tabular}

As expected, water authorities play an important role in risk management. The Dutch Ministry of Infrastructure and the Environment takes a leading role in the management of flood risks from the sea and major Dutch rivers and lakes. Both regional water boards and the provinces play a prominent role in the flood risk management of other regional rivers, lakes and canals while the regional board and the Rijkswaterstaat (Ministry of Infrastructure and the Environment) have an important function in the monitoring and management of Dutch dikes. Land use planning authorities and non-governmental stakeholders such as inhabitants are already involved in the implementation of 'room-for-the-river' measures. These actors, however, still have a limited role in the evaluation and implementation of flood mitigation measures. As mentioned before, perspectives on flood-risk management are changing, though. Consequently, it is expected that land use authorities, including the municipality, the province and the spatial planning ministry will be more instrumental in evaluating and implementing flood risks and flood risk management strategies. Since it is strived for that emergency response issues, such as possibilities for evacuation, will also play a more prominent role in future flood risk management practices, it is expected that emergency services will play a more prominent role in risk management practices as well. Insurance companies hardly play a role in flood risk management practices since the Netherlands does not have a system of flood insurance.

\subsubsection{Informational Requirements}

The investigation of information needs of spatial planners resulted in a wide variety of information needs related to flood risks. Based on the literature on risk and emergency management, these informational needs have been divided into four categories: hazards, exposure, capacities and processes. Within these categories, static information and simulated information could be distinguished as summarised in Table 2 . Static information has its time orientation in the present whereas the time focus of the simulated information is in the future. Most of these informational requirements are spatial in nature (Observed / Simulated). It could be on bio-physical or socio-economic aspects.

Table 2: Examples of Information Needed for Flood Mitigation in Landuse Planning

\begin{tabular}{|l|}
\hline \multicolumn{1}{c|}{ Examples of information needs } \\
\hline \\
$\begin{array}{l}\text { Static information: Flood prone areas; Nature of the flood, e.g. } \\
\text { flash flood, salt or fresh water. } \\
\text { Simulated information: Estimates of actual flood probabilities } \\
\text { and expected effects and consequences such as potential water } \\
\text { inundation extent, depth and velocity. }\end{array}$ \\
$\begin{array}{l}\text { Static information: Information about citizens in the area } \\
\text { exposed such as total number of inhabitants or people under } \\
\text { restrictions such as prisoners; Information about infrastructure } \\
\text { in the way of probable flood path, Vulnerable objects such as } \\
\text { schools, drinking-water supply or installations with hazardous } \\
\text { substances; Buildings characteristics such as high/low-rise } \\
\text { building (shelter), building material (strength). } \\
\text { Simulated information: Damage and number of victims or } \\
\text { buildings for a particular flooding scenario. }\end{array}$ \\
$\begin{array}{l}\text { Static information: Probability of failure of dikes and other } \\
\text { hydraulic structures such as sluices. }\end{array}$ \\
Simulated information: Simulation of dike breaches or failure \\
of hydraulic structures.
\end{tabular}




\begin{tabular}{|l|l|}
\hline $\begin{array}{l}\text { Static information: The extent of flood proofing measures or } \\
\text { the flood compatibility of the use of the ground floor of }\end{array}$ \\
buildings.
\end{tabular}

\subsection{Flood Emergency Management in the Netherlands}

In addition to examining flood risk management characteristics and informational requirements, a case study was carried out to study the performed activities, actors and information needs in flood emergency management. The results of this study are summarized below.

\subsubsection{Stakeholders and Activities}

Both emergency training and response activities are focussed on emergency response and its preparation. On the operational level, the activities carried out in emergency management can be divided into four clusters: 1) containment and control of the flood and its effects, 2) medical assistance, 3) public order and traffic management, 4) taking care of the population (Ministerie van BinnenlandseZaken 2003; Diehl and Van der Heide 2005). Table 3 gives an overview of the key stakeholders involved in these activities.

Table 3: Operational Flood Emergency Activities and Key Actors Involved (Diehl \& Van der Heide 2005)

\begin{tabular}{|ll|}
\hline Activities & Key operational stakeholders \\
\hline $\begin{array}{l}\text { Containment and } \\
\text { control of the flood } \\
\text { and its effects }\end{array}$ & $\begin{array}{l}\text { Regional fire department; Rijkswaterstaat; } \\
\text { Royal Dutch Water Life Saving Association } \\
\text { (KNBRD), Royal Netherlands Sea Rescue } \\
\text { Institution (KNRM). Military National } \\
\text { Reserve. }\end{array}$ \\
\hline Medical assistance & $\begin{array}{l}\text { (Para)medical services (GHOR); Red Cross } \\
\text { (SIGMA teams) }\end{array}$ \\
\hline $\begin{array}{l}\text { Public order and } \\
\text { traffic management }\end{array}$ & Police department \\
\hline $\begin{array}{l}\text { Taking care of the } \\
\text { population }\end{array}$ & Municipality \\
\hline
\end{tabular}

\subsection{Informational Requirements of Risk and Emergency Management}

To compare information needs in flood risk and emergency management, the risk components were used to structure the information needs within flood emergency management. The informational requirements of the fire department are worked out in more detail.
The interviewed experts stressed that it is very important to have information about the actual situation and actual consequences of the event. They often made a distinction between information that exists prior to the disaster and information that is or should be obtained during the disaster. Based on this time aspect, the information for emergency response was divided into three categories. In addition to the static and simulated information as distinguished in flood risk management, a third category was added: dynamic information. Information created or obtained during the disaster is denoted as dynamic information. Table 4 gives an overview of the information needs for the processes which fire department is responsible for during a flood. A more complete list can be found in Diehl et al. (2006) and Snoeren (2006). Spatial information related to the physical and social processes that can affect hazards and vulnerability were not mentioned as information needs//needed and therefore not mentioned in the overview table.

Table 4: Information needs for the fire brigade in case of floods

\begin{tabular}{|c|c|}
\hline & Examples of information needs \\
\hline 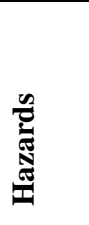 & $\begin{array}{l}\text { Static information: Flood prone areas. } \\
\text { Simulated information: Estimates of actual flood probabilities } \\
\text { and expected effects and consequences such as potential water } \\
\text { depths and velocity. } \\
\text { Dynamic information: Incident information such as scale of the } \\
\text { flood and water depths; Meteorological information such as } \\
\text { wind direction and speed, precipitation (rain/snow). }\end{array}$ \\
\hline 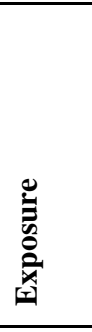 & $\begin{array}{l}\text { Static information: Information about citizens in the area } \\
\text { exposed such as total number of inhabitants; Vulnerable } \\
\text { objects such as drinking-water supply; Buildings } \\
\text { characteristics such as high/low-rise building (shelter), building } \\
\text { material (strength), cables and pipes. } \\
\text { Simulated information: Damage and number of victims for a } \\
\text { particular flooding scenario. } \\
\text { Dynamic information: Victims: trapped people, people in need; } \\
\text { Damage: property damage, unstable buildings and } \\
\text { infrastructure. }\end{array}$ \\
\hline 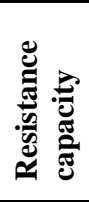 & $\begin{array}{l}\text { Static information: Probability of failure of dikes and other } \\
\text { hydraulic structures such as sluices. } \\
\text { Simulated information: Simulation of dike breaches or failure } \\
\text { of hydraulic structures. } \\
\text { Dynamic information: Actual probability of the failure of dikes } \\
\text { and other hydraulic structures. }\end{array}$ \\
\hline 龸 & $\begin{array}{l}\text { Static information: The extent of flood proofing measures or } \\
\text { the flood compatibility of the use of the ground floor of } \\
\text { buildings. } \\
\text { Simulated information: The effect of adaptive measures on } \\
\text { potential flood damage and potential number of victims. } \\
\text { Dynamic information: The actual extent of adaptive measures } \\
\text { taken in an area through temporal flood proofing, sand bags, or } \\
\text { preventive evacuation of people }\end{array}$ \\
\hline 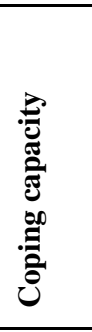 & $\begin{array}{l}\text { Static information: Capacity of emergency units such as } \\
\text { hospitals; Capacity of people to get to a safe location; } \\
\text { Possibilities for shelter; Infrastructure and Borders } \\
\text { information; Recourses such as water sources/water collection } \\
\text { or sandbags; Information for context and orientation such as } \\
\text { accessibility maps for buildings Simulated information: } \\
\text { Capacity of emergency units, people and resources } \\
\text { Dynamic information: Actual capacity of emergency units, } \\
\text { possibilities for shelter; Accessibility: in- and out-routes, traffic } \\
\text { direction, blocked or possibly blocked roads. }\end{array}$ \\
\hline 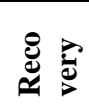 & $\begin{array}{l}\text { Static information:- } \\
\text { Simulated information: - } \\
\text { Dynamic information: Actual damage }\end{array}$ \\
\hline
\end{tabular}

${ }^{a}$ To train response activities, the dynamic information is often simulated. 


\section{INDIAN FLOOD MANAGEMENT}

\subsection{History}

After the Policy Statement of 1954 and Supplementary Statement of 1956, High Level Committee on Flood Control1957, Ministers' Committee on Floods-1964 was the important initiatives taken by the GOI. The GOI set up the National Flood Commission / Rashtriya Barh Ayog (RBA) in 1976 to study in depth the approach towards programmes of flood control measures. The RBA, which submitted its report in 1980, looked into the problem of floods in the whole of the country in a most comprehensive manner taking into account various past committees recommendations and the status of implementation thereof. Implementation of 207 recommendations from the report has been reviewed from time to time. The latest one was by the Experts' Committee under the Chairmanship of Shri. R. Rangachari former Member, CWC in 2003 which noted the slow implementation and identified 40 recommendations, which need to be followed (NDMA Guidelines, 2008).

\subsection{Institutional Framework}

Being constitutional provisions, state has the primary responsibility for Flood Management (NDMA Guidelines, 2008; Planning Commission). Laws have been enacted by many states having provisions to deal with matters related to flood control works. Central government initiative includes the enactment of the National Disaster Management Act, December 2005 and setting up of the NDMA. The National Executive Committee (NEC) with the Secretary of GOI of the ministry or department having administrative control of the subject of the DM as the Chairman and Secretaries of other ministries concerned and the Chief of the Integrated Defence Staff to the Chairman Chiefs of the Staff Committee (CISC) as Members, will assist the NDMA (NDMA Guidelines, 2008). Other Central Government mechanisms are Brahmaputra Board, Farakka Barrage Project Authority (Flood Management).

State Disaster Management Authorities (SDMAs) and State Executive Committees (SECs) need to be set up by state governments to perform similar functions at the state level. It has been proposed to set up River Basin Organisations to deal with the management of water resources at river basin level. A National Flood Management Institute (NFMI) is also proposed to set up at an appropriate location in one of the flood prone states (NDMA Guidelines, 2008).

NDMA has dedicated Flood Management guidelines. The aim of the Guidelines is to minimize vulnerability to floods and consequent loss of lives, livelihood systems, property and damage to infrastructure and public utilities.

Guidelines propose the following activities:

\section{Phase I}

These activities include identification and marking of flood prone areas on maps, preparation of close contour and flood vulnerability maps, formulating plans for expansion and modernisation of flood forecasting and warning systems, identification of priority flood protection and drainage improvement works, identification of reservoirs for review and modification of operation manuals and rule curves and undertaking special studies on problems of river erosion.
Phase II

These include implementation of the schemes for expansion and modernization of the flood forecasting and warning network, execution of flood protection and drainage improvement schemes, modification and adoption of revised reservoir operation manuals, for real-time collection of hydrometeorological data on rivers in Nepal, Bhutan and China.

\section{Phase III}

Implementation of activities, which include construction of dams and catchment area treatment (CAT) works in India as well as neighboring countries. Recurring Activities include inspection of dams, embankments and other structural measures, execution of restoration and strengthening works and expansion and modernization of flood forecasting and warning systems, are to be taken on a regular basis.

The Guidelines also mention the following Indian achievements in respect of Flood management:

\section{Structural Measures}

Since $1954,33,928 \mathrm{~km}$ of new embankments and 38,809 km of drainage channels have been constructed in the country. In addition, 2,450 town protection works have been completed and 4,721 villages have been raised above flood levels. Barring occasional breaches in embankments, these works have given reasonable protection to an area of about 18.22 million hectares.

\section{Non-structural Measures}

The MOWR and CWC had circulated in 1975, the draft bill for flood plain zoning regulations to the state governments for enactment and enforcement. The CWC has established a flood forecasting system comprising 175 stations on all major interstate rivers and is implementing the scheme for its modernisation and expansion.

Some identified gaps by the guidelines are:

- Non-availability of close contour maps and digital elevation models of flood prone areas as impediments to make reliable forecasts.

- $\quad$ Flood forecasting and warning (FF and $\mathrm{W}$ ) network of the CWC, though developed on scientific basis, does not cover all the flood prone rivers and rivulets.

- Very few river basins have been covered with automatic sensors for observations and telemetry system for communication of data.

- Flood plain zoning regulations have not been enacted and enforced by most of the states,

- There is also a lack of inflow forecasting systems for the reservoirs.

\subsection{Flood Forecasting System of Central Water Commission}

The work of flood forecasting and warning in India is entrusted with the Central Water Commission (CWC). Flood Forecasting and flood warning in India was commenced in a small way in the year 1958 with the establishment of a unit in the Central Water Commission (CWC), New Delhi, for flood forecasting for the river Yamuna at Delhi. Presently, there are 878 Hydrological and Hydro-meteorological sites being operated by CWC across the country covering 20 river basins for gauge, discharge, sediment \& water quality observations. The formulation of a forecast requires effective means of real time data communication network from the forecasting stations 
(Refer to Figure 1) and the base stations (380 number approx. at present). Wireless Communication system installed in almost 550 stations is the backbone of the communication system required for flood forecasting activities. The activity of flood forecasting comprises of Level Forecasting and Inflow Forecasting. The level forecasts help the user agencies to decide mitigating measures (Flood Management).

Figure 2 show its schematic diagram. It shows the horizontal and vertical functional relationships between the data collecting stations as well as various line departments on state and national level as flood forecasting centers \& control rooms as well as users of the forecast. Press, Radio, TV, Police etc are also part of this schematic diagram.

Figure 3 A shows the interactive data flow observations locations, which can be clicked upon to get the attribute data of a particular location. Figure $3 \mathrm{~B}$ shows the data extraction window. It provides options for query based selection of data using (spatial / thematic) state, district, basin or river name as filter.

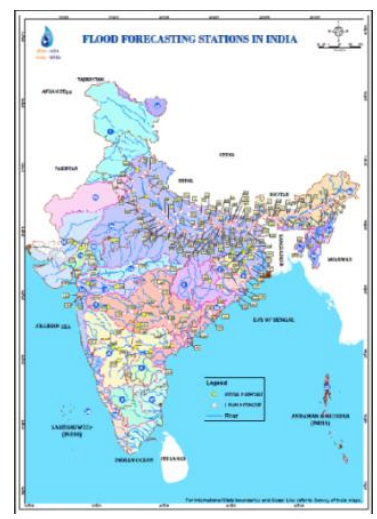

Figure 1: Flood Forecasting Stations in India; Source: Central Water Commission

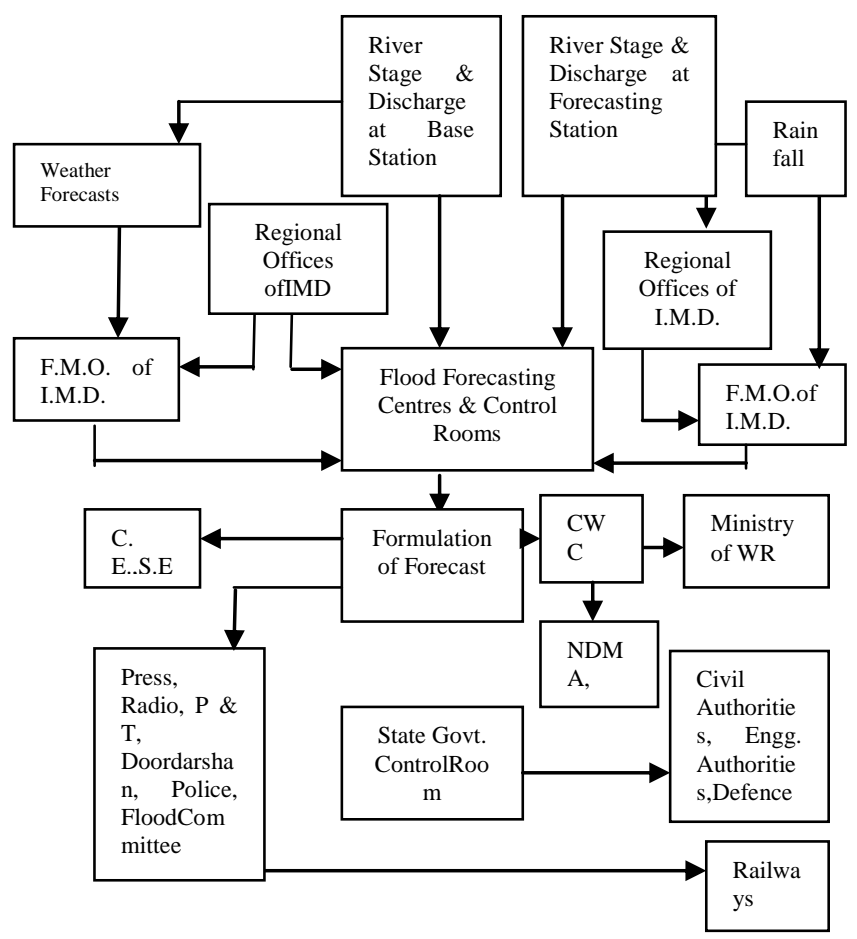

Figure 2: Flood Forecasting and Warning Present SystemSchematic Diagram; Source: Roy V. D., 2014

\section{DISCUSSION}

The main lesson derived from the exploration of flood risk and emergency management activities is that information has to flow across and between different actors involved in different flood management practices. A spatial information infrastructure that covers both risk and emergency management allows the required exchange of information. Therefore, the development of a spatial information infrastructure that integrates risk and emergency management deserves extra attention. These statements are discussed in more detail in a comparison between the characteristics of flood management and those of informational requirements.

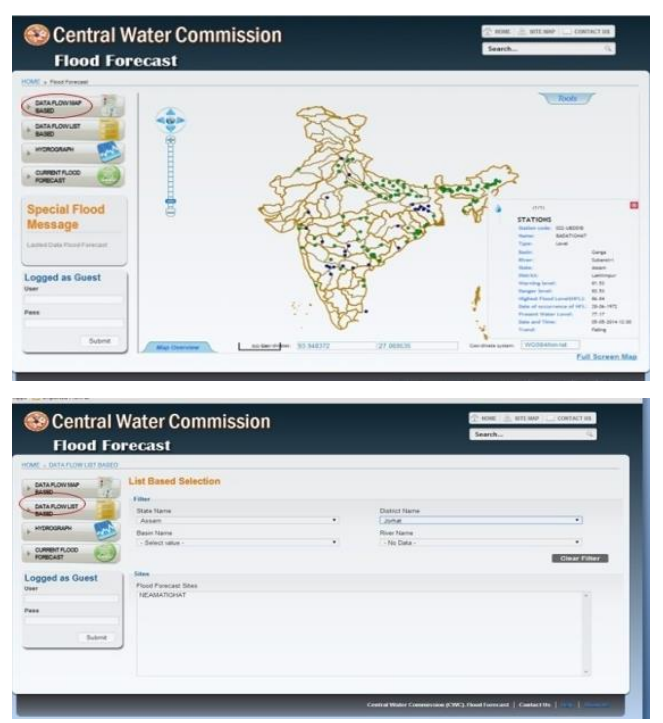

Figure 3 A \& B: Data Flow Map and Data Flow List Based Selection Windows of CWC Flood Forecast ; Source: Central Water Commission

\subsubsection{Stakeholders and Activities}

The exploration of flood management activities in Netherlands has shown that flood risk and emergency management activities profoundly differ. Emergency management activities are often carried out under high time pressure and ask for tactical skills, whereas flood risk management activities are carried out under less time pressure and ask for strategic skills.

Within both flood risk and emergency management, many stakeholders are involved on different scale / levels. As shown in our exploration, emergency preparedness and response is often the domain of emergency units such as medical services, the fire department and police services, while mitigation and recovery are often the domains of the planning, engineering and public works departments.

The exploration, however, has revealed a changing perspective on flood management, especially in the field of flood risk management. Within Dutch flood risk management, more attention is paid to flood consequences and possibilities for emergency management. In this light, flood risks are managed in a more integrated way in which both hazards, exposure, capacities and processes are taken into account. Land use planning was//is increasingly being considered an important instrument to reduce flood consequences. As a result, flood risk management is expected to become a more important issue in land use planning. 
In India, Disaster Management is not on an advanced stage and there is no clear-cut distinction of risk and emergency management concepts in practice.

Flood Management in India using spatial information is at nascent stage although various actors are doing several activities for flood management. This include dedicated Flood Management Guidelines by National Disaster Management Authortiy (NDMA), State and District Level Authorities local level planning and actions, Satellite Images based observation, early warning and situation analysis by National Remote Sensing Centre, Research conducted by various disaster management related organizations.

Indian Flood Management guidelines stress on spatial information for different phases of activities as well as to plug the identified gaps. The Flood Forecast System of the Central Water Commission has a Graphical User Interface (GUI) which provides spatial as well as statistical information on click of a station in Data Flow Map Window. Data Flow List Window allows user to filter the query on different spatial scale of administrative boundaries (State, District) or natural boundaries / Features (Basin, River). Further, this allows to directly select Forecasted Sites which again provides spatial as well as statistical information.

\subsection{Informational Requirements}

The informational requirements of two stakeholders involved in two different domains of flood and emergency management have been discussed in more detail, as in the case of Netherlands: the land use planning department and the fire department. Even though the activities of the land use planners and the fire department differed, it was interesting to observe that informational requirement considerably overlapped. The informational requirements with respect to the static and simulated information especially overlapped. Land use planners emphasized the need for information about flood emergency aspects such as the possibilities for emergency response and evacuation. On the other hand, representatives of the fire department mentioned the importance of the spatial data obtained by the land use planners, such as the risk maps. As a consequence, flood risk and emergency management can be seen as activities where informational requirements are increasingly overlapping (Figure 4.).

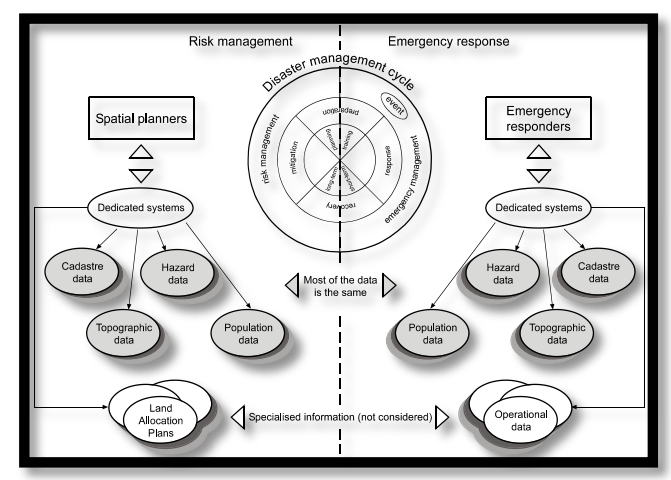

Figure 4: Information Overlap between Risk and Emergency Management

Real time dynamic information was mainly required for activities related to flood emergency management. Nevertheless, the real time information obtained during flood emergency activities can be used to improve simulated information in other flood management activities. Dynamic information about the development of a flood wave, for example, can be used to improve flood models for flood risk management and emergency trainings.

\section{NEED FOR AN INTEGRATED SPATIAL INFORMATION STRUCTURE}

Flood management in Netherlands and India shows that flood management is a set of activities that have to be carried out in collaboration with multiple agencies. These agencies should not only operate together within one phase of flood management, for example, during the response phase, but stakeholders involved in different phases should work together as well. For example, the revealed attention for flood response issues in Dutch flood risk management practices requires the cooperation between land use planners, normally involved in risk management, and emergency response units, normally involved in flood emergency management. This could be the same in case of Indian flood management practices by various agencies. In India, although, there is no such distinction of risk and emergency management activities in context of disaster management.

A closer examination of informational requirements shows that it is very likely that informational requirements between flood management activities and the management of other hazards overlap as well. For example, a considerable part of the information about a society's capacity to deal with flood hazards will also be useful to assess the risks of industrial hazards, such as the release of toxic gases. As a result, information needs to flow across and between agencies and flood risk and emergency management domains.

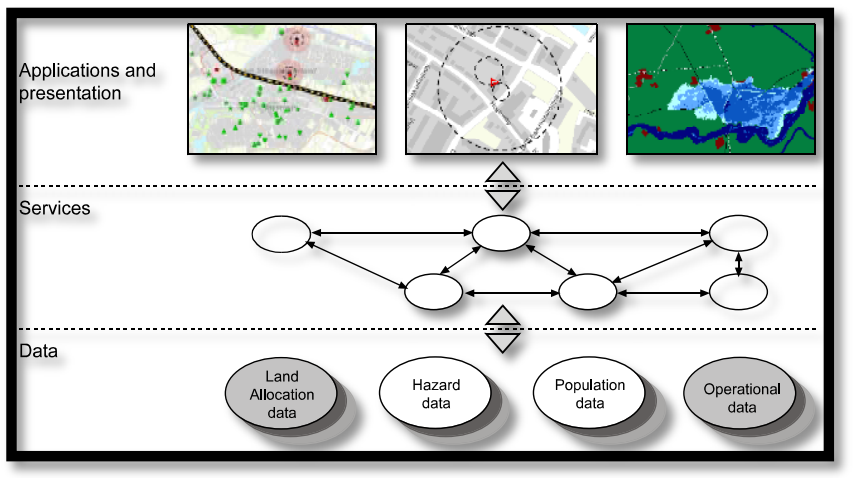

Figure 5: A Service Oriented Spatial Information Infrastructure

In this respect, an appropriate spatial information infrastructure that enables the exchange of information is increasingly considered as a critical aspect to support risk management activities (Greene 2002; Cutter 2003; Köhler and Wächter 2006; Mansourian et al. 2006; Parker et al. 2007; Grothe et al. 2008). The widely applied Service Oriented Architecture approach offers an interesting concept for such an information infrastructure. Within this concept, the required information for each stakeholder is acquired through the composition of a relevant package of information services. These datasets and services can be acquired from a great variety of available userspecific systems such as monitoring systems (e.g., early warning systems, modelling and simulation systems such as flood risk models or emergency management systems). Through a selection of services, the user is not connected to all available databases for risk management but only to a relevant 
selection. Furthermore, these services can be presented in different application, to meet specific user requirements and user interfaces and to enable the implementation of services from one application into another (Figure 5).

In addition to the information, services and application, the spatial information infrastructure requires technical standards such as the ISO standards, access networks such as the internet or through satellites, policies that comprise policies to share information and policies for responsibilities towards information production and maintenance of required spatial data sets, and finally, people who use the spatial information, together with information suppliers and any value-adding agents in between (Williamson and Rajabifard 2003; Mansourian et al. 2006). In India, although the disaster management is primarily a state responsibility but a spatial information structure following data standards compatible with Indian NSDI and OGC standards can help to integrate the information structure for disaster management such as flood management.

The development and application of open standard by the Open Geospatial Consortium, INSPIRE or GMES, for example, increasingly facilitates the exchange of geographic information and services. Nevertheless, the emergency response sectors and/or other local organisations often maintain much of the information. Sometimes, it is unclear whether two emergency sectors possess the same information; maps and plans maintained by the police brigade might be not available for ambulances or fire department. This tendency is very strong in the case of spatial information. The different sectors used to have individual information systems for management of information, which could not communicate with each other and therefore were unable to share information (ACIR 2005). The overlap in informational requirements implies that spatial information systems should allow different actors involved in both flood risk and emergency management to operate together (i.e. to understand each other) before and in any critical situation. These systems should also allow the most appropriate information to be generated, found and delivered in a fast and efficient manner.

We recommend having joint research efforts between India and Netherlands in context of disaster management to learn from each other's experience. A wide range of institutional arrangements should be made in both countries to achieve integrated spatial information infrastructure. Experiences on the development of such a structure have already shown that the bottleneck in information exchange is often not really in the technical aspects--technically, these problems can be solved-but mostly in reaching agreements between different information holders, standardisation of products, legal aspects and regulations (see Diehl and Van der Heide 2005; Zlatanova 2013).

\section{REFERENCES}

ACIR, 2005. De vrijblijvendheid voorbij. Op naar een effectieve multidisciplinaire informatievoorziening bij grootschalig gezamenlijk optreden in onze gedecentraliseerde eenheidsstaat Ministerie van Binnenlandse Zaken en Koninkrijksrelaties, Den Haag

MIKE 11, DHI. http://www.mikebydhi.com/products/mike11(November 2014)
Bottelberghs PH., 2000. Risk analysis and safety policy developments in the Netherlands. J. Hazard. Mater. 71(1-3):5984

Brazier AM, Greenwood RL, 1998. Geographic information systems: A consistent approach to land use planning decisions around hazardous installations. J. Hazard. Mater. 61(1-3):355361

Central Water Commission, Flood Forecast System. Website: http://www.india-water.gov.in/ffs.

Contini SS, Bellezza F, Michalis D, Christou CD, Kirchsteiger C , 2000. The use of geographic information systems in major accident risk assessment and management. J. Hazard. Mater. 78(1-3):223-245

Cova TJ , 2005. GIS in emergency management In: Longley PA et al (eds) Geographical Information Systems: Principles, Techniques, Management, and Applications. Second Edition Abridged. John Wiley \& Sons, New York

Craciunescu V, Stancalie G, Diamandi A, Rodica PM, 2006. Flood monitoring using on-line support system for spatial information management. In: Schanze J et al (eds) Flood risk management: Hazards, vulnerability and mitigation measures. Springer, Berlin

Cutter SL, 2003. The vulnerability of science and the science of vulnerability. Ann. Assoc. Am. Geogr. 93(1):1-12

Central Water Commission; CWC National Flood Forecasting Network; Website: http://indiawris.nrsc.gov.in/wrpinfo/index.php?title=CWC_National_Floo d_Forecasting_Network

Diehl S, Neuvel JMM, Zlatanova S, Scholten HJ, 2006. Investigation of user requirements in the emergency response sector: the Dutch case. In:

Flood Management; CWC National Flood Forecasting Network; Website: http://indiawris.nrsc.gov.in/wrpinfo/index.php?title=CWC_Nati onal_Flood_Forecasting_Network

Fiedrich, F. and S. Zlatanova, 2013. Emergency mapping, In: P. Bobrowsky (Eds.); Encyclopedia of Natural Hazards, Springer, Heidelberg, New York, Dordrecht, London, pp. 272276

Diehl S, Van der Heide J, 2005. Geo Information Breaks through Sector Think. In: Oosterom $P$ et al (eds). Geoinformation for disaster management, Delft2005, / Springer, City, pp. 85-108

Greene RW, 2002. Confronting catastrophe: a GIS handbook. ESRI Press, Redlands, CA

Grothe MJM, Landa HC, Steenbruggen JGM , 2008. The value of Gi4DM for transport and water management. In: Zlatanova and $\mathrm{Li}$ (eds) Geospatial Information Technology for Emergency Response. Taylor and Francis Group, London

HEC-RAS, US Army Corps of Engineers;

Website: http://www.hec.usace.army.mil/ 
Kaviani A., Rajabifard A., 2014. VGS based framework for disaster response; Coordinates, Volume X, October 2014

Köhler P, Wächter J, 2006. Towards an open information infrastructure for disaster research and management: Data management and information systems inside DFNK. Nat. Hazards. 38(1-2):141-157

Mansourian AA, Rajabifard A, ValadanZoej MJ, Williamson I , 2006. Using SDI and web-based system to facilitate disaster management.Comput. Geosci. 32(3):303-315

Ministerie van Binnenlandse Zaken, 2003. Handboek rampenbestrijding Ministerie van Binnenlandse Zaken, Den Haag

Ministerie van Infrastructuur en Milieu, Interprovinciaal Overleg IPO, \& Unie van Waterschappen., 2012. Flood risk in the Netherlands VNK2: The method in brief. Technical Background. Den Haag: VNK2 project office

Ministerie van Verkeer en Waterstaat, 2007. Programma waterveiligheid 21e eeuw Ministerie van Verkeer en Waterstaat. Accessed 20 Jun 2007

Ministerie van Verkeer en Waterstaat, Inspectie Verkeer en Waterstaat, 2006. Primaire waterkeringen getoetst. Landelijke rapportage toetsing 2006 Ministerie van Verkeer en Waterstaat, Den Haag

NDMA Guidelines, 2008. National Disaster Management Guidelines, Management of Floods;

Neuvel, J. M. M., 2009. Geographical dimensions of risk management: the contribution of spatial planning and Geo-ICT to risk reduction. Wageningen: Wageningen University.

Parker CJ, MacFarlane R, Philips C, 2007. Integrated emergency management: Experiences and challenges of a national GI provider, Ordnance Survey. In: S. Zlatanova and Li J (eds) GI-technology for emergency response Taylor\& Francis London
Planning Commission, 2011. Report of Working Group on Flood Management and Region Specific Issues for XII Plan, New Delhi

Pattusamy S., Purusothaman B.M., 2014. Disaster Management and mapping using Remote Sensing and GIS; J. of Computation in Biosciences and Engineering. V1I3. DOI: 10.15297/JCLS.V1I3.06

Schanze J, 2006. Flood risk management: A basic framework. In: Schanze $\mathrm{J}$ et al (eds) Flood Risk Management: Hazards, Vulnerability and Mitigation Measures. Springer, Berlin

Schneiderbauer S, 2007. Risk and vulnerability to natural disasters - from broad view to focused perspective. Freien Universität Berlin, Berlin

Snoeren G., 2006. Rampenbestrijdingsprocessen. Actoren, werkwijze en data. GDI4DM project, Arnhem

STOWA, 2008. FLIWAS International flood warning and information system STOWA.

Roy V. D. , 2014. Flood Forecasting and Warning Mechanism, Annual Conference of Relief Commissioners/Secretaries of Disaster Management of States to review preparedness for South West Monsoon, New Delhi

Williamson I, Rajabifard A, 2003. Developing Spatial Data Infrastructures: From Concept to Reality. Taylor \& Francis, London

Zlatanova, S., 2013. Flood and flood riks: mapping, monitoring and damage assessment, in: The value of Geoinformation for risk and disaster management, JB of GIS, pp.33-43

Zlatanova, S. and A.G. Fabbri, 2009. Geo-ICT for risk and disaster management. In: Scholten, van Velde\&vanManen (Eds.), Geospatial technology and the role of the location in science, Springer, Dordrecht, Heidelberg, Londen, New York, pp. 239-266

Zlatanova, S., D. Holweg and M. Stratakis, 2007. Framework for multi-risk emergency response, In: Tao\&Li (Eds.), Advances in Mobile Mapping Technology, Taylor\&Francis, London, ISPRS Book Series, pp. 159-171 